\title{
Gambaran Darah Katak Fejervarya limnocharis di Lahan Pertanian yang Menggunakan Pestisida di Sumatera Barat
}

\author{
YELVITA SARI $^{1}$, DJONG HON TJONG ${ }^{1}$, RESTI RAHAYU $^{1}$ \\ ${ }^{1}$ Jurusan Biologi, Fakultas Matematika dan Ilmu Pengetahuan Alam, Universitas Andalas \\ J1. Dr. M. Hatta No 1, Padang, Sumatera Barat, 25163 \\ email: yelvitas84@gmail.com
}

\begin{abstract}
Fejervarya limnocharis are amphibians which generally can be found in agriculture area. The high intensity of pesticide application in agricultural area can lead to alteration of physiological aspects of organism inhabiting that area. Quantitative examination of hematology aspect can be conducted to evaluate physiological condition of species. This research was aimed to find out about hematology profile of $F$. limnocharis living in agriculture area using pesticide in West Sumatera. Thus, examinations of erythrocytes, leukocytes, hemoglobin concentrations, and hematocrit values collected from $F$. limnocharis living in three different areas have been conducted. The data gained have been compared with normal blood value of various amphibians species from previous research. The result acquired respectively for three locations show that total of erythrocytes were in normal range, which were $1,616 \times 106 / \mathrm{mm} 3 ; 1,539 \times 106 / \mathrm{mm} 3$; and 1,712 x 106/mm3; hemoglobin concentration were lower than normal range, which constituted 4,06 g/dL; $4 \mathrm{~g} / \mathrm{dL}$; and 4,18 g/dL; hematocrit values have normal range, which made up 40,06 \%; 40,14\%; and 45,7 \%; total of leukocytes were higher than normal range, which were $27,450 / \mathrm{mm} 3 ; 49,934 / \mathrm{mm} 3$; and $22,040 / \mathrm{mm} 3$. Usage of pesticide in agriculture area causes alteration of some hematological aspect.
\end{abstract}

Keywords: Fejervarya limnocharis, hematology profile, pesticide, West Sumatera

\section{INTISARI}

Fejervarya limnocharis merupakan amfibia yang umum ditemukan di sekitar lahan pertanian. Intensitas penggunaan pestisida yang tinggi di lahan pertanian dapat memicu terjadinya perubahan aspek fisiologi organisme yang hidup di kawasan tersebut. Untuk mengevaluasi kondisi fisiologi suatu spesies dapat dilakukan pemeriksaan kuantitatif terhadap darah. Penelitian ini bertujuan untuk mengetahui gambaran darah $F$. limnocharis yang hidup di lahan pertanian yang mengaplikasikan pestisida di Sumatera Barat. Pada penelitian ini dilakukan pemeriksaan terhadap jumlah eritrosit, leukosit, kadar hemoglobin, dan nilai hematokrit darah $F$. limnocharis yang dikoleksi dari tiga lahan pertanian berbeda. Hasil yang didapatkan dibandingkan dengan nilai darah normal berbagai spesies amfibia yang telah diteliti oleh peneliti sebelumnya. Didapatkan hasil secara berurutan untuk ketiga lokasi, jumlah eritrosit berada dalam kisaran normal yaitu 1,616 x 106/mm3; 1,539 x 106/mm3; dan 1,712 x 106/mm3; kadar hemoglobin lebih rendah dari kisaran normal yaitu 4,06 g/dL; $4 \mathrm{~g} / \mathrm{dL}$; dan 4,18 g/dL; nilai hematokrit dalam kisaran normal yaitu 40,06 \%; 40,14 \%; dan 45,7 \%; dan jumlah leukosit yang lebih tinggi dari kisaran normal yaitu 27,450/mm3; 49,934/mm3; dan 22,040/mm3. Penggunaan pestisida di lahan pertanian menyebabkan perubahan pada beberapa aspek kuantitatif darah.

Kata Kunci: Fejervarya limnocharis, pestisida, profil darah, Sumatera Barat

\section{PENDAHULUAN}

Amfibia merupakan salah satu organisme penting di ekosistem teresterial maupun akuatik. Keberadaannya sering digunakan sebagai bioindikator kerusakan lingkungan (Waddle, 2006). Hal ini dikarenakan amfibia 
memiliki sensitivitas yang tinggi terhadap perubahan lingkungan. Penelitian yang dilakukan oleh Ezemonye dan Ilechie (2007) menunjukkan bahwa amfibia yang hidup di lahan tercemar pestisida cenderung mengalami gangguan fisiologi dan bahkan menunjukkan tingkat kematian yang tinggi.

Fejervarya limnocharis atau katak tegalan merupakan salah satu jenis amfibia yang sering ditemukan di lahan pertanian. Menurut IUCN (2014) kategori konservasi katak ini masih tergolong ke dalam resiko rendah dengan populasi di alam yang relatif besar dan stabil. Namun adanya pencemaran akibat penggunaan pestisida di lahan pertanian menjadi suatu ancaman yang berpotensi membahayakan keberadaan jenis ini di masa yang akan datang.

Sumatera Barat merupakan provinsi yang memiliki lahan pertanian yang cukup luas yakni mencapai 2.353.685 hektar (Yaherwandi, 2009). Sebagai kawasan pertanian penggunaan berbagai jenis pestisida masih intens dilakukan oleh petani. Menurut Rusli (2002) penggunaan pestisida oleh petani di Sumatera Barat tergolong sangat intensif dan telah melebihi dosis yang direkomendasikan. Frekuensi penggunaan pestisida sebanyak 1-2 kali seminggu dan lebih dari 10 kali dalam satu musim tanam. Tingginya intensitas penggunaan pestisida oleh petani di Sumatera Barat berpotensi menimbulkan dampak negatif terhadap berbagai organisme yang hidup di kawasan tersebut salah satunya amfibia jenis $F$. limnocharis.

Sejumlah penelitian melaporkan adanya pengaruh penggunaan pestisida di lahan pertanian terhadap status kesehatan $F$. limnocharis (Thammchoti et al., 2012, Hedge \& Krishnamurthy, 2014). Selain itu penelitian secara eksperimental di laboratorium oleh Gurushankara et al. (2016) menunjukkan bahwa perlakuan methil parathion (organofosfat) pada $F$. limnocharis menyebabkan rendahnya tingkat kelulusan hidup dan meningkatnya kematian. Pestisida juga dilaporkan telah memicu terjadinya perubahan terhadap nilai darah pada amfibia jenis lainnya. Penelitian yang dilakukan oleh
Paunescu dan Ponepal (2011) menunjukkan bahwa pemberian herbisida Roundup pada jenis Pelophylax ridibundus menyebabkan terjadinya peningkatan jumlah leukosit diiringi dengan menurunnya eritrosit. Sementara itu Mahananda dan Mohanty (2012) melaporkan bahwa pemberian pestisida malathion dari golongan organofosfat dengan kosentrasi dan waktu yang berbeda pada Bufo melanostictus berpengaruh terhadap penurunan jumlah hemoglobin, eritrosit, dan leukosit.

Pemeriksaan aspek fisiologi darah yang meliputi jumlah eritrosit, jumlah leukosit, kadar hemoglobin dan nilai hematokrit sebagai pengaruh senyawa kimia di lingkungan merupakan aspek penting yang diperlukan untuk menilai resiko yang ditimbulkan oleh senyawa tersebut terhadap suatu organisme (Williams et al., 2000). Penelitian ini bertujuan untuk mengetahui gambaran fisiologi darah katak $F$. limnocharis yang hidup di lahan pertanian yang menggunakan pestisida di Sumatera Barat.

\section{METODE}

Pengoleksian Sampel. Sampel katak $F$. limnocharis dikoleksi dari tiga lokasi berbeda di Sumatera Barat. Lokasi pengoleksian meliputi sawah dan perkebunan di kelurahan Limau Manis, Kecamatan Pauh, Kota Padang, Jorong Aia Karuah, Kanagarian Salimpek, Kecamatan Lembah Gumanti, Kabupaten Solok dan Jorong Pincuran Tujuh, Kanagarian Koto Laweh Kecamatan X Koto, Kabupaten Tanah Datar.

Koleksi sampel dilakukan pada malam hari menggunakan lampu senter dengan cara mengarahkan sorotan lampu tepat pada organ mata dengan tujuan melumpuhkan penglihatan agar katak tidak melompat sehingga memudahkan penangkapan. Sampel dimasukkan ke dalam kotak transparan yang telah diisi air dan di bawa ke laboratorium Fisiologi Hewan Jurusan Biologi FMIPA Universitas Andalas dalam keadaan hidup. Selanjutnya dilakukan pemeriksaan terhadap aspek fisiologi darah yang meliputi jumlah sel darah merah, jumlah leukosit, kadar hemoglobin, dan nilai hematokrit. 
Pengambilan Sampel Darah. Katak yang akan diambil darahnya dibius menggunakan kloroform. Selanjutnya dilakukan pembedahan. Sampel darah diambil melalui jantung menggunakan jarum suntik yang telah diolesi EDTA. Selanjutnya darah yang telah diambil disimpan ke dalam tabung vakum khusus berisi larutan EDTA. Sampel darah dalam tabung vakum disimpan sementara di dalam termos yang telah diisi batu es untuk pemeriksaan lebih lanjut.

Penghitungan Jumlah Eritrosit. Penghitungan jumlah eritrosit dilakukan secara manual menggunakan hemositometer dengan mengencerkan darah dalam pipet thoma kemudian dihitung dalam kamar hitung. Darah dalam tabung vakum dihisap menggunakan pipet thoma sel darah merah sampai skala 0,5. Selanjutnya dihisap larutan pengencer hayem hingga skala 101. Darah dalam pipet thoma dihomogenkan dengan cara menggoyangkan pipet secara perlahan. Selanjutnya darah dipipetkan ke dalam hemositometer tipe improved neubauer untuk diamati di bawah mikroskop dengan perbesaran 10x40 lalu dihitung dengan menggunakan tally counter. Jumlah eritrosit dihitung dengan menggunakan rumus berikut:

$\sum \mathrm{E}=\frac{\mathrm{Ne} \mathrm{X} \mathrm{P}}{0,02}$

Keterangan:

$\sum \mathrm{E}:$ Jumlah eritrosit total

$\mathrm{Ne}$ : Jumlah eritrosit pada lima kotak yang dihitung

$\mathrm{P} \quad$ : Angka pengenceran (200 kali)

0,02 : Volume total darah dalam lima kotak yang dihitung

Penentuan Jumlah Leukosit. Darah dalam tabung vakum dihisap menggunakan pipet thoma leukosit sampai skala 0,5. Selanjutnya dihisap larutan pengencer turk hingga skala 11. Darah dalam pipet thoma dihomogenkan dengan cara menggoyangkan pipet secara perlahan. Selanjutnya darah dipipetkan ke dalam hemositometer tipe improve neubauer untuk diamati di bawah mikroskop dengan perbesaran 10x40 lalu dihitung dengan menggunakan tally counter. Jumlah sel darah merah dihitung dengan menggunakan rumus berikut:

$$
\sum \mathrm{L}=\frac{\mathrm{N} 1 \mathrm{X} P}{0,4}
$$

Keterangan:

$\sum \mathrm{L} \quad$ : Jumlah total leukosit

N1 : Jumlah leukosit pada 64 kotak yang dihitung

$\mathrm{P} \quad$ : Angka pengenceran (100 kali)

0,4 : Volume total darah dalam 64 kotak yang dihitung

Penentuan Kadar Hemoglobin. Kadar hemoglobin dihitung dengan menggunakan hemometer Sahli. Masukkan $\mathrm{HCl} 0,1 \mathrm{~N}$ ke dalam tabung sahli sampai skala 10, lalu tambahkan sebanyak $20 \mathrm{~mL}$ sampel darah yang akan diuji, aduk dengan menggunakan batang pengaduk sampai homogen. Selama pengadukan lakukan penambahan setetes demi setetes akuades. Setelah homogen, warna darah disamakan dengan warna larutan standar, kadar hemoglobin dari sampel darah adalah angka yang ditunjukkan oleh dinding tabung setinggi permukaan cairan dalam tabung.

Penentuan Nilai Hematokrit. Sampel darah yang akan diuji diambil dengan menggunakan tabung mikrokapiler hematokrit, salah satu ujung yang berlawanan dengan bagian yang terkena darah disumbat dengan wax. Selanjutnya masukkan tabung kapiler ke dalam mikrosentrifus jenis Kubota KH-120 dan disentrifuse dengan kecepatan $10.000 \mathrm{rpm}$ selama lima menit. Nilai hematokrit dibaca dengan skala ukur hematokrit dalam satuan persen.

Analisis Data. Data berupa jumlah sel darah merah, jumlah leukosit, kadar hemoglobin, dan nilai hematokrit dianalisis dengan membandingkan nilai rata-rata antara setiap lokasi sampling dengan dengan nilai standar yang ditetapkan berdasarkan Glomsky et al. (1997), Kundu and Roychoudhury (2009), Arserim and Mermer (2008), Gul et al. (2011), dan Sulastri dkk (2014).

\section{HASIL}

Hasil pemeriksaan kuantitatif sel darah pada katak Fejervarya limnocharis yang berasal dari beberapa lahan pertanian di Sumatera Barat pada penelitian ini dapat dilihat pada Tabel 1. 
Tabel 1. Rata-rata nilai fisiologi darah F. limnocharis dari lahan pertanian di Sumatera Barat

\begin{tabular}{lcccc}
\hline \multirow{2}{*}{ Parameter } & \multirow{2}{*}{ Standar } & \multicolumn{3}{c}{ Lokasi Sampling } \\
\cline { 2 - 5 } & & I & II & III \\
\hline Eritrosit ( $\mathbf{~ 1 0} / \mathbf{m m}^{\mathbf{3}}$ & $0,17-2,57^{*}$ & 1,616 & 1,539 & 1,712 \\
\hline Hemoglobin (g/d) & $5,6-12,10^{* * * *}$ & 4,06 & 4 & 4,18 \\
\hline Hematokrit (\%) & $10-70^{* * *}$ & 40,06 & 40,14 & 45,7 \\
\hline Leukosit $(/ \mathbf{m m}$ & $1.875-5200^{* *}$ & 27.450 & 49.934 & 22.040 \\
\hline
\end{tabular}

Keterangan:

*Glomsky et al., (1997); Arserim and Mermer (2008); Kundu and Roychoudhury (2009); Sulastri dkk (2014). ** Arserim and Mermer (2008); Kundu and Roychoudhury (2009); Sulastri dkk (2014). *** Kundu and Roychoudhury (2009); Aserim and Mermer (2008). **** Kundu and Roychoudhury (2009); Arserim and Mermer (2008), Gul et al. (2011); Sulastri dkk (2014). Lokasi Sampling I: Padang; II: Tanah Datar; III: Alahan Panjang

\section{PEMBAHASAN}

Jumlah Eritrosit. Penghitungan jumlah rata-rata sel darah merah $F$. limnocharis yang berasal dari ketiga lokasi sampling dibandingkan dengan nilai standar yang digunakan menunjukkan hasil yang berada dalam kisaran normal. Hal ini kemungkinan karena sebagian pestisida yang masuk ke dalam tubuh telah dimetabolisme dan dieksresikan ke luar tubuh. Menurut Indraningsih dan Sani (2006) beberapa jenis pestisida terutama golongan organofosfat diketahui sangat cepat dimetabolisme dan dieksresikan ke luar tubuh. Akibat adanya proses metabolisme dan ekskresi ini kemungkinan residu pestisida yang masih tersisa tidak berpengaruh terhadap jumlah sel darah merah. Sejumlah penelitian telah melaporkan tidak adanya pengaruh signifikan dari berbagai jenis pestisida terhadap jumlah sel darah merah. Penelitian pada kelinci putih New Zealand yang diberi pakan tercemar pestisida tidak menunjukkan adanya pengaruh terhadap jumlah sel darah merah (Permana, Minarti, dan Sjofjan, 2013). Penelitian Khogali et al. (2005) juga melaporkan tidak adanya efek signifikan pemberian pestisida dimethoat 40 E.C terhadap nilai sel darah merah pada tikus albino.

Jumlah Leukosit. Jumlah rata-rata leukosit $F$. limnocharis yang berasal dari ketiga lokasi dibandingkan dengan nilai standar yang digunakan (Kundu and Roychoudhury, 2009; Arserim and Mermer, 2008; Sulastri dkk 2014) berada di atas kisaran normal. Tingginya jumlah rata-rata leukosit $F$. limnocharis dari ketiga lokasi ini kemungkinan terkait dengan fungsinya sebagai komponen darah yang berperan penting dalam sistem pertahanan tubuh. Rastogi (2007) menyatakan bahwa meningkatnya jumlah leukosit merupakan sinyal infeksi yang disebabkan oleh bahan kimia tertentu yang masuk ke dalam tubuh. Adanya aplikasi pestisida di ketiga lokasi sampling diduga memicu terjadinya aktivasi sistem pertahanan tubuh melalui peningkatan jumlah leukosit. Selain itu kerusakan dan kematian jaringan yang terdapat pada sejumlah sampel kemungkinan juga memicu peningkatan produksi leukosit yang ikut berperan dalam mencerna bahan asing penyebab kerusakan dan menghancurkan selsel yang rusak. Hal ini sejalan dengan Rogers (2011) yang menyatakan bahwa sel-leukosit yang telah terbentuk akan bermigrasi ke organ yang rusak dan kemudian terlibat dalam penghancuran sel-sel yang telah rusak dan mati. Penelitian oleh Muralidharan (2012) yang menunjukkan adanya peningkatan jumlah leukosit ikan Cyprinus carpio yang terpapar pestisida golongan organofosfat fenthion dengan kejadian inflamasi pada sayatan histologi lambung.

Sejumlah penelitian eksperimental di laboratorium juga menunjukkan efek signifikan paparan pestisida terhadap peningkatan jumlah leukosit pada beberapa hewan. Salah satunya Paunescu dan Ponepal (2011) menemukan bahwa perlakuan herbisida roundup dosis $0,138 \times 10^{-3} \mathrm{ml} / \mathrm{Bb}$ secara intraperitoneal pada katak Pelophylax ridibundus berpengaruh nyata dalam meningkatkan jumlah leukosit. 
Kadar Hemoglobin. Kadar hemoglobin rata-rata $F$. limnocharis dari ketiga lokasi sampling yang didapatkan pada penelitian ini dibandingkan dengan nilai standar yang digunakan Kundu and Roychoudhury 2009; Arserim and Mermer, 2008) berada di bawah kisaran normal. Selain itu penurunan kadar hemoglobin yang ditemukan dalam penelitian ini tidak sejalan dengan jumlah sel darah merah yang berada pada kisaran normal. Hal ini bertolak belakang dengan Ganong (2008) yang menyatakan bahwa kadar hemoglobin berbanding lurus dengan jumlah sel darah merah. Kondisi tersebut kemungkinan terjadi sebagai akibat adanya gangguan pada sintesis zat besi (heme) yang merupakan komponen penting dalam sintesis hemoglobin. Diduga keberadaan pestisida mengganggu proses sintesis zat besi melalui mekanisme penghambatan terhadap glikolisis aerobik yang menghasilkan suksinil KoA pada siklus Krebs. Hoffbrand (2005) menyatakan bahwa suksinil KoA merupakan salah satu komponen penting dalam sintesis heme. Adanya hambatan terhadap glikolisis aerobik secara tidak langsung akan berpengaruh pada proses sintesis heme.

Selain itu pengaruh pestisida dalam menurunkan kadar hemoglobin darah diduga berlangsung melalui mekanisme hambatan kerja enzim yang berperan dalam sintesis hemoglobin. Mekanisme hambatan berlangsung sama dengan mekanisme hambatan enzim oleh logam berat. Hal ini merujuk kepada Joshaghani et al. (2007) yang menyatakan bahwa mekanisme intoksifikasi pestisida kemungkinan memiliki kesamaan dengan intoksifikasi logam berat. Salah satu logam berat yang memiliki dampak terhadap penurunan kadar hemoglobin adalah timbal. Intoksifikasi timbal terhadap darah berlangsung melalui penghambatan fungsi enzim sufhidril oleh timbal untuk mengikat Amino Levulinic Acid (ALA) menjadi porpoblinogen, serta protoporfirin menjadi hemoglobin (Musthapia dan Sunarno, 2006). Penurunan kadar hemoglobin dalam darah sebagai akibat perlakuan pestisida telah ditemukan oleh Patil et al. (2008) pada tikus yang diperlakukan dengan berbagai dosis pestisida methomyl. Joshagahani et al. (2007) juga menemukan adanya penurunan kadar hemoglobin yang tidak seiring dengan jumlah sel darah merah pada pekerja di pabrik pestisida.

Nilai Hematokrit. Nilai hematokrit darah yang berasal dari ketiga lokasi sampling dibandingkan dengan standar yang digunakan menunjukkan nilai yang berada pada kisaran normal. Hal ini sejalan dengan jumlah sel darah merah yang juga berada dalam kisaran normal. Menurut Ganong (2008) dan Rastogi (2007) hematokrit merupakan persentase jumlah sel darah merah dalam keseluruhan plasma darah, oleh karena itu nilai hematokrit darah akan berbanding lurus dengan jumlah sel darah merah.

\section{KESIMPULAN}

Didapatkan nilai fisiologi darah katak $F$. limnocaharis menunjukkan jumlah sel darah merah yang berada dalam kisaran normal $\left(0,18-2,06 \times 10^{6} \mathrm{~mm}^{3}\right)$. Kadar hemoglobin berada di bawah kisaran normal (6 - $17 \mathrm{gr} / \mathrm{dl})$. Nilai hematokrit berada dalam kisaran normal (19 - $70 \%$ ). Jumlah leukosit berada di atas kisaran normal $\left(1200-8200 / \mathrm{mm}^{3}\right)$.

\section{DAFTAR PUSTAKA}

Arserim SK and Mermer A. 2008. Hematology of the Uludag Frog, Rana macrocnemis Boulenger, 1885 in Uludag National Park (Bursa, Turkey). Journal of Fisheries and Aquatic Sciences. vol 25(1): 39-46.

Ezemonye LIN and Ilechie I. 2007. Acute and Chronic Effects of Organophosphate Pesticides (Basudin) to Amphibian Tadpoles (Ptychadena bibroni). African Journal of Biotechnology. vol 6 (13): 1554-1558.

Ganong WF. 2008. Buku Ajar Fisiologi Kedokteran Edisi 20 (Diterjemahkan oleh dr. H.M Djauhari Widjajakusumah). Jakarta: EGC.

Glomsky CA, Tamburlin J, Hard R and Chainami M. 1997. The Phylogenetic Odyssey of the Erythrocyte. The Amphibians Histology and Histopathology. vol 12: 147-170. 
Gul C, Tosonuglu M, Erdogan D and Ozdamar D. 2011. Changes in the Blood Composition of Some Anurans. Acta Herpetologica. vol 6 (2): 137-14.

Gurushankara HP, Krishnamurthy SVB, Vasudev V. 2016. Effect of Methyl Parathion on Survival and Development of Tadpoles of Indian Cricket frog Fejervarya limnocharis. The Journal of Tropical Life Science. vol 6(1): 41-46.

Hegde G and Krishnamurthy SV. 2014. Analysis of health status of the frog Fejervarya limnocharis (Anura: Ranidae) living in rice paddy fields of Western Ghats, using body condition factor and AChE content. Ecotoxicology Environmental Contamination. vol 9 (1): 69-76.

Hoffbrand AV, Catovsky D, Tuddenham EGD and Green AR (Editor). 2005. Postgraduate Hematology Sixth Edition. New Jersey: Blackwell Publishing ltd.

Indraningsih dan Sani Y. 2006. Residu Pestisida dalam Otak Sapi Perah di Lembang, Jawa Barat. Jurnal Ilmu Ternak dan Veteriner. vol 11(1): 76-83.

IUCN. 2014. Fejervarya limnocharis. http://www.iucnredlist.org. diakses pada Desember 2016.

Joshagani HR, Moansourian AR, Kalavi K and Salimi S. 2007. Hematologic Indices in Pesticides Faktory Workers. Journal of Biology Science. vol 7 (3): 566-569.

Khogali FA, Sheikh JB and Abdel Rahman S. 2005. Histopathological and Hematological Effects of Dimethoate $40 \mathrm{EC}$ on Some Organs of Albino Mice. Journal of King Saudi Universit. vol 18 (2): 73-87.

Kundu CY and Roychoudhury S. 2009. Malathion-induced sublethal toxicity on the hematology of cricket frog (Fejervarya limnocharis). Journal of Environmental Science and Health. Part B (44): 673-680.

Mahananda MR and Mohanty BP. 2012. Toxicity on Biochemical and Hematological Parameters in Bufo melanostictus (Schneider) (Common Indian Toad) Exposed to Malathion,
Pesticides. Advance in Chemical Botanical Pesticides. Burla, Orissa: INTECH Open Access Publisher. pp: 412.

Muralidharan L. 2012. Haemato-Biochemical Alterations Induced by Chronic Exposure to Fenthion in Cyprinus carpio. Trends in Fisheries Research. vol 1 (3): 19-25.

Musthapia I dan Sunarno MTD. 2006. Dampak Polutan Timbal pada Ikan dan Manusia. Seminar Nasional Limnologi. Jakarta: LIPI.

Patil JA and Govindwar SP. 2008. Biochemical Effects of Various Pesticides on Sprayers of Grape Gardens. Indian Journal of Clinical Biochemistry. vol 18 (2): 16-22.

Paunescu A and Ponepal CM. 2011. Effect of Herbicide Roundup to The Physiological Indices in Marsh Frog Pelophylax ridibundus. Scientific Papers. Journal of the University of Agricultural Science and Veterinary Medicine Series A. vol 55: 1222-5339.

Permana DA, Minarti S dan Sjofjan O. 2013. Karakteristik Profil Darah Kelinci New Zealand White yang Diberi Pakan Limbah Daun Kubis (Brassica Oleracia) Sebagai Pakan Utama. [Skripsi]. Malang: Fakultas Peternakan, Universitas Brawijaya.

Rastogi SC. 2007. Essentials of Animal Physiology Fourth Edition. New Delhi: New Age International (P) Limited Publisher.

Rogers K (Editor). 2011. Blood Physiology and Circulation. New York: Britannica Educational Publishing.

Rusli. 2002. Inventarisasi Penggunaan Pestisida oleh Petani Kubis di Kecamatan Lembah Gumanti Kabupaten Solok. Jurnal Stigma.vol X (4): 344-346.

Sulastri S, Titrawani, Windarti. 2014. Gambaran Darah Rana Erythraea (Schlegel 1837) Di Wilayah Kampus Universitas Riau Pekanbaru. Jurnal Online Mahasiswa FMIPA. vol 1 (2): 303-313.

Thammachoti P, Khonsue W, Kitana J, Varanusupakul P, Kitana N. 2012. 
Journal of Environmental Protection. vol 3: 1403-1408.

Waddle JH. 2006. Use of Amphibians as Ecosystem Indicator Species.

[Dissertation]. Florida: University of Florida.

Williams PL, James RC, Roberts SM (Editor). 2000. Principles of Toxicology
Environmental and Industrial Applications Second Edition. Toronto: Johnwiley \& Sons, Inc.

Yaherwandi. 2009. Struktur Komunitas Hymenoptera Parasitoid Pada Berbagai Lanskap Pertanian di Sumatra Barat. Jurnal Entomologi Indonesia. vol 6(1): 1141. 